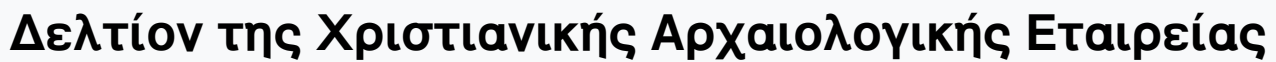

Tó 26 (2005)

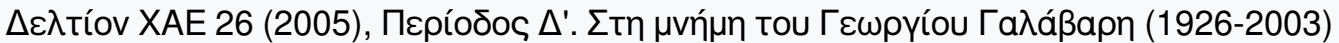

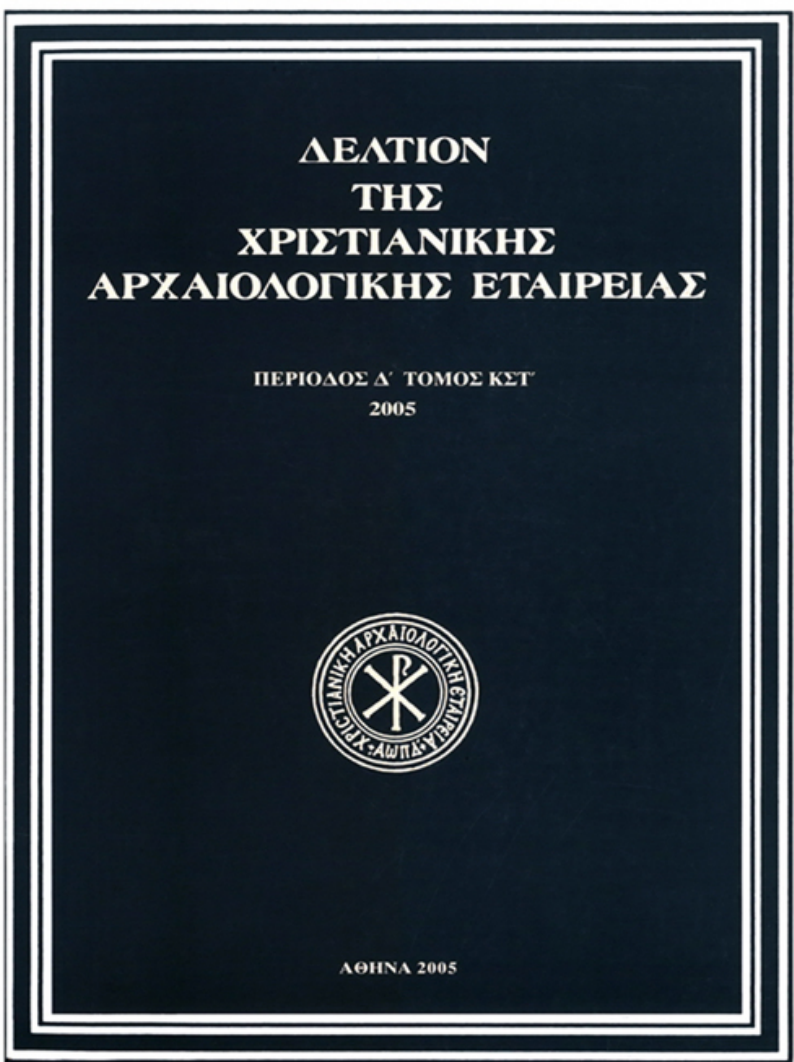

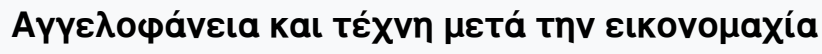

Glenn PEERS

doi: $10.12681 /$ dchae.452

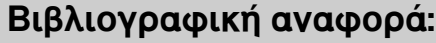

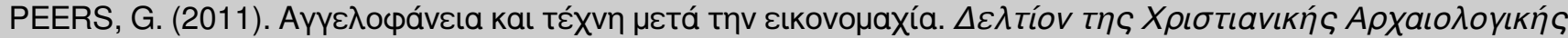
Eтaıркía c, 26, 339-344. https://doi.org/10.12681/dchae.452 


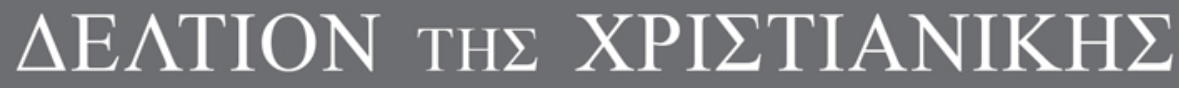 APXAIO $\Lambda$ ОГКН $\Sigma$ ETAIPEIA $\Sigma$}

Angelophany and Art after Iconoclasm

Glenn PEERS

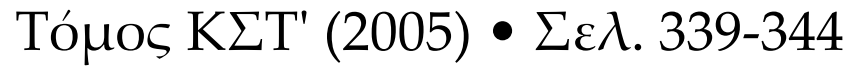

A@HNA 2005 


\section{Glenn Peers}

\section{ANGELOPHANY AND ART AFTER ICONOCLASM ${ }^{1}$}

$\mathrm{T}_{\mathrm{r}}$ he prophets had particular importance in iconophile theology because they represented irrefutable witness of divine disclosure; and epiphany confirmed by scripture was central to iconophile defense of making images. For instance, the Oratio on angels by Theodore of Stoudios (759-826) demonstrated the importance of attested witness, as well as the significance of engaging such enigmatic and symbolic revelations $^{2}$. Likewise, in an Oratio on John the Baptist, Theodore made explicit the central place the prophets had for iconophile justification of images ${ }^{3}$. Although angels are imperceptible and formless by nature, they are made manifest in some sensible fashion through witnessed epiphanies ordained by God; they are, therefore, representable ${ }^{4}$.

Iconophiles insisted throughout the controversy on the importance of prophetic visions without entering into specifics or explaining all aspects ${ }^{5}$. They relied largely on the sanction of scriptural description of divine manifestations to provide them with an unassailable case that supported their contention that Christ, though divine, could be represented as human. They also used these manifestations to provide historical evidence for the perception of divine presence and, therefore, for the making of images. And their writings signaled openness to epiphanies and their symbolic interpretation. Iconophiles approached visions in two complementary ways: visions were historical occurrences, and they have the capability of generating meaning for Christians willing to engage such manifestations allegorically.

The precise degree of influence that this iconophile theory on witness and allegory had on art production after Iconoclasm ended in 843 has been a matter of scholarly debate.

\footnotetext{
${ }^{1}$ In memory of George Galavaris, who first introduced me to angels when I was his student at McGill University. Abbreviations in notes are from the $O D B$.

${ }^{2} P G 99,736-41$.

${ }^{3} P G 99,752$.

${ }^{4}$ See my Subtle Bodies: Representing Angels in Byzantium, Berkeley 2001, and Imagination and Angelic Epiphany, BMGS 21 (1997), 113-31.

${ }^{5}$ See, above all, L. Brubaker, Vision and Meaning in Ninth-Century
}

Evidently, iconophile theologians stressed the historical and symbolic value of epiphany in their defense of images, but the paucity and ambiguity of the material remains hinder any analysis of effects of this theoretical defense on postIconoclastic art. Leslie Brubaker has argued persuasively for a new sense of direct and intimate participation in visions in the art produced after 843 . This short essay follows some of the implications of that insight for understanding images of angelophany in the post-Iconoclastic period.

The illustration of the vision of Isaiah in the ninth-century Vatican Christian Topography (gr. 699, fol. 72v; Fig. 1), not present in the two later manuscripts of 'Cosmas's' work, shows two different fields of action: in the bottom righthand corner, a seraphim, here depicted as a winged man, is leaning forward to place the burning coal in Isaiah's mouth, while in the middle ground Christ is enthroned between two six-winged seraphim. This illustration literally depicts two different moments in the epiphany of Isaiah, the seraphim putting a coal in the prophet's mouth and his vision of God (6:1ff.). The subject of the vision, that is, the Lord and the seraphim, is given prominence in the illustration. Moreover, Christ is himself depicted in the illustration, showing the Christian belief in the prefiguring nature of this Old Testament vision ${ }^{6}$.

Despite the prominence of Christ and flanking seraphim, Isaiah's witness is fundamental to the depiction since it gives the event historical veracity and narrative context. However, the placement and activity of the prophet determine a particular approach by the viewer that enhances his or her position with regard to Isaiah and his ability to 'see'. In the illus-

\footnotetext{
Byzantium, Cambridge 1999, 19-58. Recent work on the epiphany and art includes M. Barasch, Das Buch Ezechiel in der frühchristlichen Kunst, in Die Sichtbarkeit des Unsichtbaren, Stuttgart 2003, 119-30, and N. Zchomelidse, Das Bild im Busch. Zu Theorie und Ikonographie der alttestamentischen Gottesvision im Mittelalter, ibid., 175-8.

${ }^{6}$ See H.L. Kessler, Medieval Art as Argument, in Iconography at the Crossroads, Princeton 1993, 61, also in his Spiritual Seeing, Philadelphia 2000.
} 


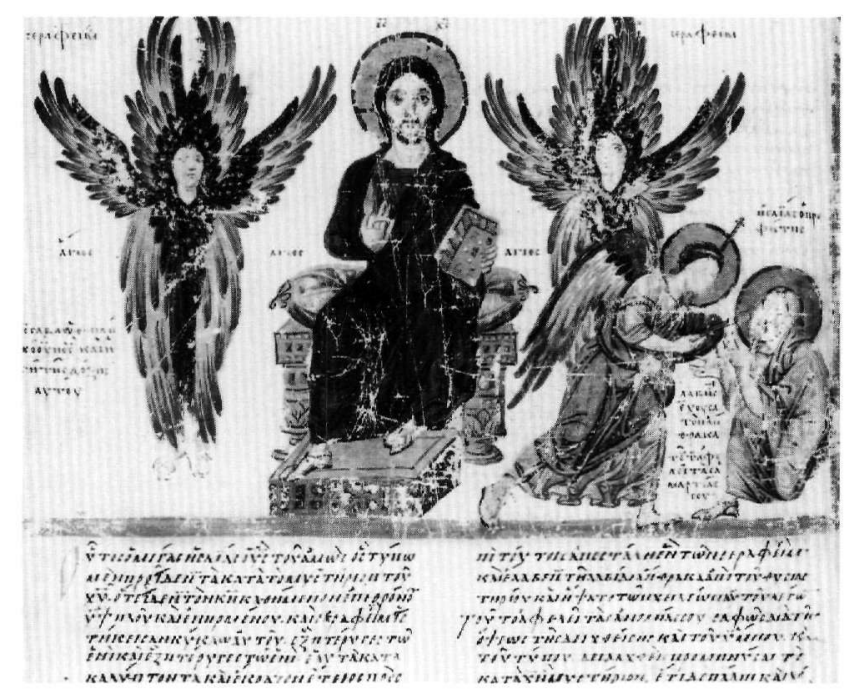

Fig. 1. Vision of Isaiah. Christian Topography, second half of ninth century. Biblioteca Apostolica Vaticana, gr. 699, fol. 72v.

tration, the approaching angel blocks Isaiah's line of vision, and so Christ and the seraphim cannot be seen at the same moment by the prophet. The angel's two feet are placed over the ground line of the illustration that separates the image and text on the page, thus signifying that the prophet and angel are in a forward part of the picture plane. Looking directly out of the picture plane at the viewer, Christ is presented frontally and large in scale compared to Isaiah. Isaiah does not gaze at this manifestation directly and looks laterally across the picture plane at the anthropomorphic seraphim looming over him. In this way, he is not 'face-to-face' with "the Lord sitting upon a throne, high and lifted up..." (6:1) in the initial phase of the epiphany and is engaged in the later part of the epiphany (6:6-7).

By keeping Isaiah removed from the central epiphany depicted in the page, the illustrator indicates that Christ flanked by the seraphim is a projection of Isaiah's vision that is continuing in the lower right-hand corner ${ }^{7}$. The absence of Isaiah from the initial epiphany and the gaze of Christ involve the viewer directly in the vision as a witness. The disjuncture in these two scenes of the coal and the vision of God within the same frame allows the viewer to assimilate his or her vision of Christ and the seraphim with Isaiah's own. Moreover, in this vision shared by both prophet and viewer, the viewer is made superior by his or her knowledge of the event's typological significance since Christ is depicted enthroned as the Lord of the Old Covenant. This example demonstrates that a direct and intimate relationship be- tween viewer and image is an important aspect of manuscript illustration in the period after Iconoclasm.

Like the depiction of the vision of Isaiah, the illustration of the vision of Ezekiel in that same manuscript (74r; Fig. 2) underscores the importance of witness and the assimilation of viewer with that witness. The illustration faithfully follows the biblical text (Ez. 1:4ff.) in which Ezekiel saw a vision of God, "a brightness was about it, and out of the midst thereof as the colour of amber, out of the midst of the fire" (1:4). In the upper register of the illustration, Christ is shown enthroned in a mandorla; inscriptions recalling the text of Ezekiel are within and around the mandorla. Ezekiel stands to the right of Christ while a hand from heaven gives him a scroll (3:1-3). Once again, the illustrator signals the privileged position of the viewer compared to Ezekiel by the prophet's placement. In this illustration, Christ faces forward and meets the gaze of the viewer; and he also gesture with his right hand, making further and direct contact with the viewer. Moreover, the lower rim of Christ's mandorla overlaps the horizontal band, "the likeness of the firmament" (1:22), that separates the cherubim below from Christ and Ezekiel. In the upper register, the placement of Ezekiel's feet indicates that he is standing behind the dividing band and thus not in a position to see face-on the mandorla of Christ as it is depicted on the page. The central part of the illustration is a projection of the prophet's vision that allows the viewer to assume a direct and privileged relationship to the epiphany witnessed by Ezekiel.

Although not associated with these art-historical developments, the origins of the representation of the miracle of the Archangel Michael at Chonae in western Asia Minor also partake of that renewed interest in witness and participation. That miracle, where Michael appeared to save his shrine and hermit, Archippus, from inundation, was the most famous instance of Michael's intervention in earthly affairs. The cult of Michael, and this miracle along with it, was established early in the Common Era, but the cult received special attention in the ninth century ${ }^{8}$. The first extant representation of the miracle is found in the church of St. John, north chapel \#4, at Güllü Dere (ca. 900) ${ }^{9}$. The programme of the chapel is funerary and includes representa-

\footnotetext{
${ }^{7}$ See K. Weitzmann, The Ode Pictures of the Aristocratic Psalter Recension, DOP 30 (1976), 76.

${ }^{8}$ See, for example, R. Janin, Églises CP, Paris 1969, 337, 347.

${ }^{9}$ See C. Jolivet-Lévy, Les églises byzantines de Cappadoce, Paris 1991, $37 \mathrm{ff}$.
} 
tions of the Deesis, Pentecost and the vision of Eustathius. Gabriel and Michael, the guardian archangels, are represented to either side of the earlier door, which is now stoned up. Though Michael is dressed in imperial robes, the inscription accompanying him recalls the miracle at Chonae. Above the door to Michael's right, a partial figure is discernible, inscribed 'Archipas'; in light of Michael's inscription, this figure must be identified as Archippus, the hermit rescued at Chonae.

This representation is not typical of subsequent conventions for the miracle. Here the large figure of the Archangel, paired with Gabriel, is clearly represented in his role as guardian, which he manifests on behalf of the deserving faithful. The small Archippus is here a testimony of Michael's appearances on earth on behalf of his followers. The subject of the epiphany made manifest to Archippus is gigantic in comparison to the hermit, comparable for instance to the proportions of human and divine figures in the Vatican 'Cosmas.' In this way, the viewer is made to understand the intensity of the epiphany by the Archangel's awesome size; moreover, the approachable context of the small chapel occasions a familiarity of viewer and Archangel. This depiction of epiphany then reveals its affinities with other post-Iconoclastic representations of angelic epiphany in its emphasis on immediacy and presence, as well as on historical witness ${ }^{10}$.

The earliest example of an illustration of the miracle at Chonae, in its canonical scheme, is found in the so-called 'Menologion' of Basil II (ca. 1000, Vat. gr. 1613, p. 17; Fig. $3)^{11}$. The illustration of the miracle at Chonae in the manuscript presents a dramatic scene of active intervention that stands out in the file of rather mechanical martyrdoms and frontal, motionless figures in this extensively illustrated manuscript. The figure of Michael is uncommonly active for this manuscript, and it is also unlike his other representations here. In his appearance to Joshua (p. 3; Fig. 4), Michael is depicted like an immobile general; while on the page for the Feast of the Synaxis of the Archangels (p. 168; Fig. 5), Michael hovers motionlessly over the abyss into which the vanquished devils fall. Evidently, the illustration of the miracle at Chonae is from an outside source, distinct from the other illustrated scenes of Michael, as well as from the rest of the saints in the manuscript.

Archippus's stance and gesture, contrasted to Michael's, are

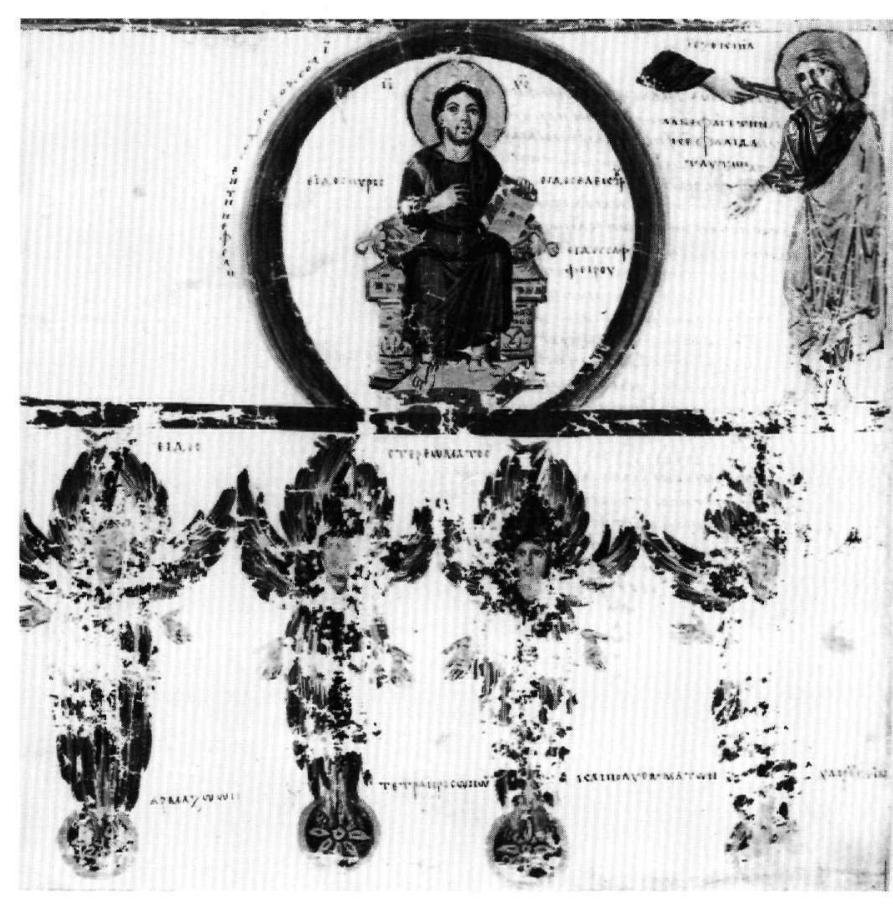

Fig. 2. Vision of Ezekiel. Christian Topography, second half of ninth century. Biblioteca Apostolica Vaticana, gr. 699, fol. 74r.

typical of a venerable worthy witnessing an appearance of the divine. They fall into a formulaic range depicting a Christian holy man looking for guidance. But Archippus is also granted an epiphany, a concentrated vision of the divine. Joshua is shown in the 'Menologion' illustration as absolutely dumbstruck after he learns the identity of Michael. He, like Daniel (Dan. 8:17-8), falls to the ground in fear and wonder. The composed hermit, Archippus, reveals the distinctly benevolent character of the appearances of the Archistrategos to the heroes of the New Covenant. Archippus's upraised hands are a stable gesture for venerable figures inviting and receiving divine aid, and his gesture, and all it implies, is a sign for imitation by the viewer-worshipper. The figure is an invitation to direct participation and assimilation.

The history of the image of the miracle at Chonae before the Menologion is unknown, but some conclusions can be reached by an examination of the images of the miracle in the 'Menologion' and illustrated Metaphrastian Menologia

\footnotetext{
${ }^{10}$ See my Holy Man, Supplicant and Donor: On Representations of the Miracle of the Archangel Michael at Chonae, MedSt 59 (1997), 173-82.
}

\footnotetext{
${ }^{11}$ See The Glory of Byzantium. Art and Culture of the Middle Byzantine Era A.D. 843-1261, Exhibition Catalogue, New York 1997, 100-1.
} 


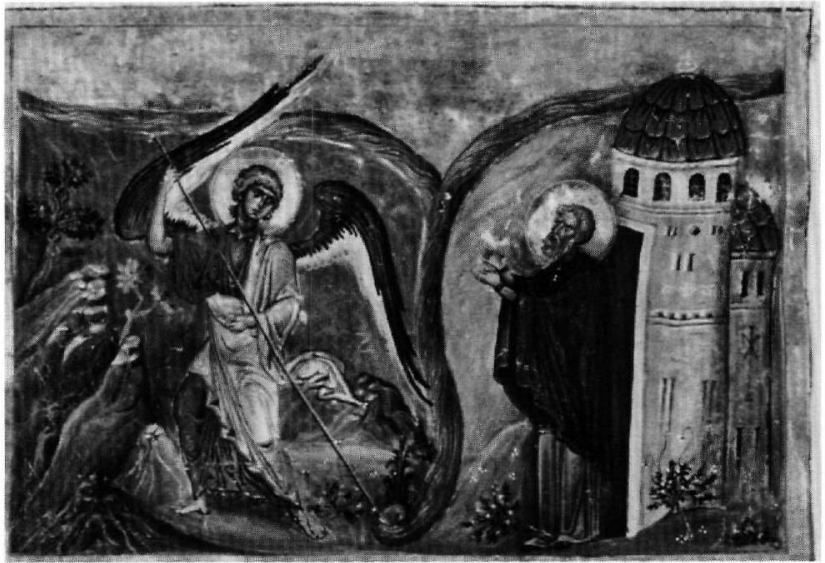

Fig. 3. Miracle at Chonae. 'Menologion' of Basil II, ca. 1000. Biblioteca Apostolica Vaticana, gr. 1613, p. 17.

for September, British Library 11870, fol. 60r (Fig. 6) and Marciana gr. Z 586, fol. $62 \mathrm{v}$, both dating from the second half of the eleventh century ${ }^{12}$. Sirarpie Der Nersessian proposed that few, if any, of the illustrations of either the Metaphrastian Menologion or that of Basil II were invented for the manuscripts, and that, in fact, they share a common prototype, namely an illustrated Synaxarion created during the reign of Leo VI (886-912). The illustrations and texts of the Menologion of Metaphrastes derived from earlier sources, and these were adapted to the particular kind of decoration chosen for each manuscript.

The depictions of the miracle at Chonae show none of the clear deviations in iconography that allowed Der Nersessian to trace illustrations to a given text, namely a Synaxarion ca. 900. These illustrations in the British Library and Marciana manuscripts are simply cases of formal, autonomous choices made by the painters, not omissions or additions dependent on textual versions. All three show the same essential elements: church, hermit, rivers and Archangel.

No mention of the miracle being celebrated on 6 September exists before the 'Menologion' of Basil II. The late ninthearly tenth-century Typikon neglects to mention Chonae in the feast of Michael on that day; and the miracle does not appear in the slightly later Synaxarion ${ }^{13}$. The 'Menologion' of Basil appears to belong to a separate stemma from the Synaxarion published by Delehaye, and Der Nersessian sug-

\footnotetext{
12 N.P. Ševčenko, Illustrated Manuscripts of the Metaphrastian Menologion, Chicago 1990, 120, 176.
}

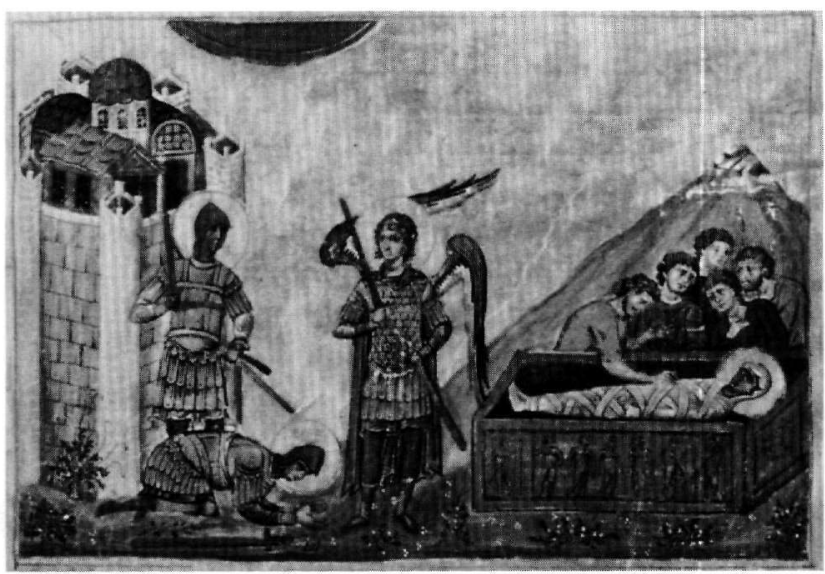

Fig. 4. Joshua. 'Menologion' of Basil II, ca. 1000. Biblioteca Apostolica Vaticana, gr. 1613, p. 3.

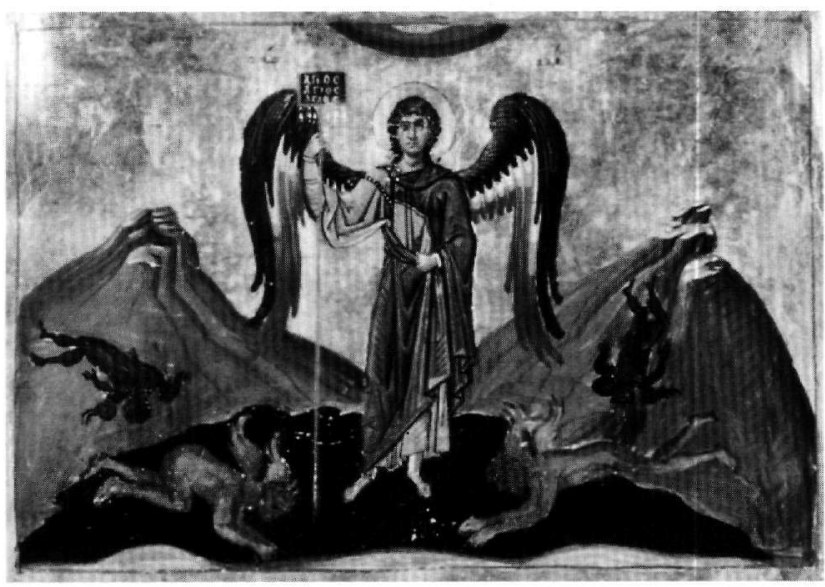

Fig. 5. Synaxis of the Archangels, 'Menologion' of Basil II, ca. 1000. Biblioteca Apostolica Vaticana, gr. 1613, p. 168.

gested that the 'Menologion' may be closer to the archetype than Delehaye's since no text in the 'Menologion' dates after the beginning of the tenth century; likewise, the illustrations discussed here must belong to an equally early, illuminated archetype. From the evidence available, the original source for these illustrations in these Menologia was a liturgical manuscript, that is, the late ninth/early tenth-century illustrated Synaxarion ${ }^{14}$.

\footnotetext{
${ }^{13}$ Mateos, Typikon, I, 17. Synaxarium CP, 19-20.

${ }^{14} \mathrm{~S}$. Der Nersessian, The Illustrations of the Metaphrastian Menolo-
} 
The early history of the images of the miracle at Chonae must certainly have had an intimate connection with the shrine at Chonae itself. Gabriel Millet asserted that many of the images in the Menologion of Basil II were taken from ancient models created at the sanctuaries themselves ${ }^{15}$. Indeed, the iconography of the miracle at Chonae in the 'Menologion' of Basil II has been shown to be distinct in character and form from other images of the Archangel and other saints in that manuscript. The feast of the miracle of Chonae was celebrated at the Sosthenion near Constantinople according to the tenth-century Synaxarion, and it may have been at that site that the iconography was developed and seen by the artists of the 'Menologion' of Basil $\mathbf{I I}^{16}$. However, the shrines at Chonae and of the Sosthenion have disappeared, and Millet's thesis cannot be tested in this case. Perhaps the iconography was established at Chonae but only achieved its canonical form after Iconoclasm at the capital, specifically at the important healing shrine of Sosthenion ${ }^{17}$. The witness of the hermit and of the landscape itself is the significant feature of the image of the miracle at Chonae. In the legend, Michael appears in a variety of forms; he appears as a disembodied voice in a dream, as an inexplicable flame emanating from the water, and in the grand epiphany as a pillar of fire, thunder and earthquake. The protean quality of the Archangel posed problems of perception and description in the text, and, in the face of these difficulties, witness was an important security for cult. The monk Archippus is the ethical centre of the legend and also the primary proof of the epiphany itself. Furthermore, the landscape is witness to the Archangel's intervention in a radical way since Michael realigns the source and remakes it as an even more miraculous site. The representation of the miracle has, from this point of view, the same emphasis on witness as other post-iconoclastic images. And the hermit as ethical model in the hagiography and in liturgy encourages the viewer to fashion his or her own entreaty to the Archangel in a similarly orthodox fashion. The representation, too, falls into the same category of increased intimacy and identification of viewer and image that characterizes the representation after Iconoclasm.

A new emphasis on historical veracity and reality determined art after Iconoclasm, and the assimilation of prophet/ holy man and viewer was a direct result of depicting epipha-

gion, in Late Classical and Mediaeval Studies in Honor of Albert Mathias Friend, Jr., Princeton 1955, 225.

${ }^{15}$ G. Millet, L'art byzantin, in Histoire de l'art, Paris 1905-1929, I, 1, 238.

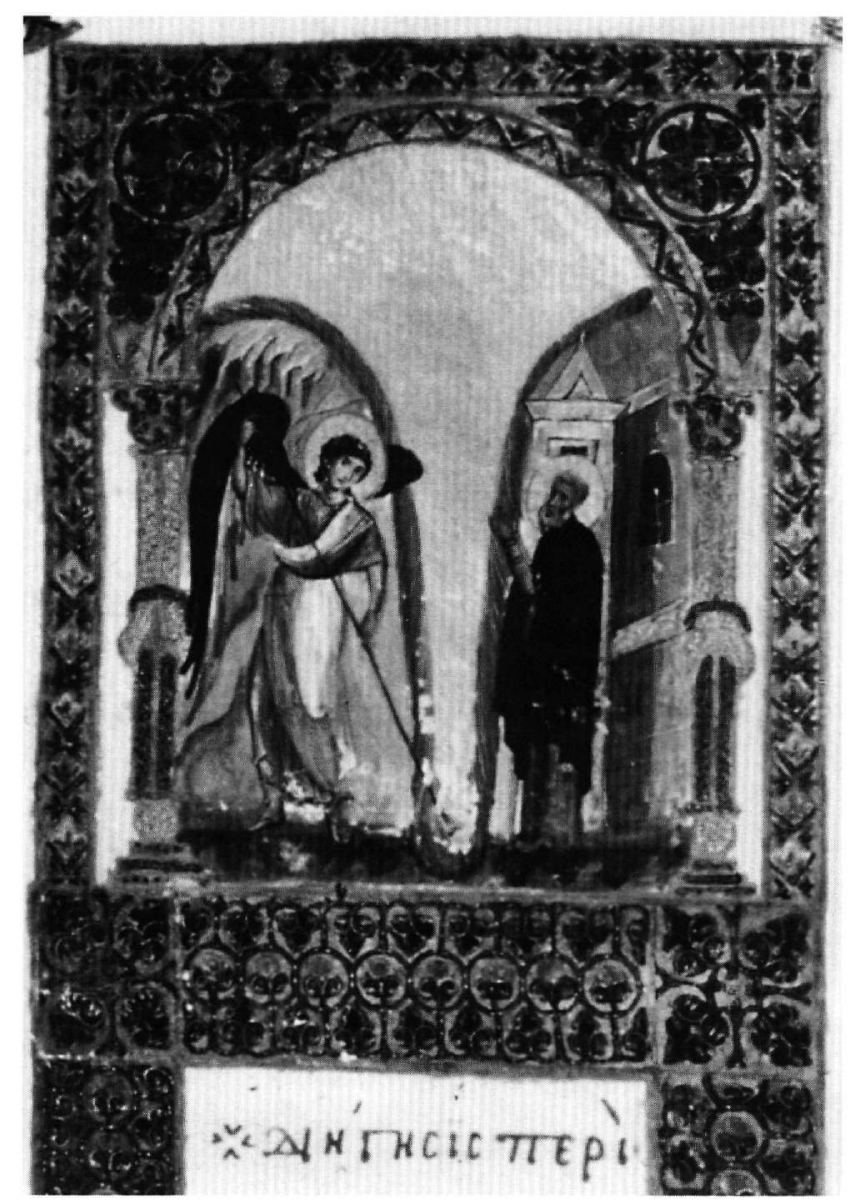

Fig. 6. Miracle at Chonae. Metaphrastian Menologion, second half of the eleventh century. British Library, cod. 11870, fol. 60r.

ny with full knowledge of the pictorial conceits that integrate the viewer directly and intimately within the action depicted. A perception of continuity was also stressed by some writers of the ninth and tenth centuries, and the iconography of angelophany reveals that awareness. Yet the context of art after Iconoclasm shows a heightened awareness of the power of art to involve and make divine epiphany more really present, both as historical occurrences and as ongoing revelation of a difficult and abstract spiritual reality. The miracle at Chonae and prophetic visions had new life in that period of intense interest in angels and their images.

University of Texas

\footnotetext{
${ }^{16}$ Synaxarium $C P, 20,21-3$.

${ }^{17}$ See my The Sosthenion near Constantinople: John Malalas and Ancient Art, Byz 68 (1998), 110-20.
} 


\section{Glenn Peers}

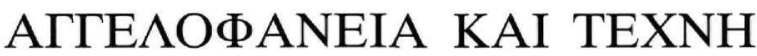 META THN EIKONOMAXIA}

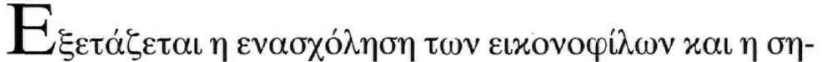

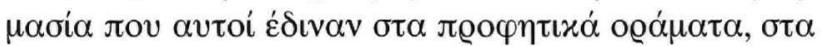

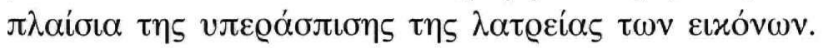

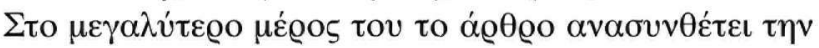

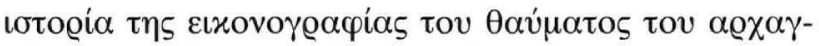

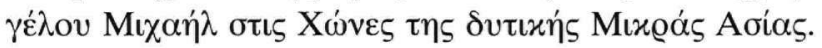

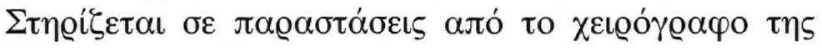

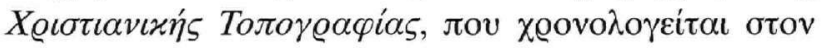
9o $\alpha \iota \omega ́ v \alpha$ (Vat. gr. 699).

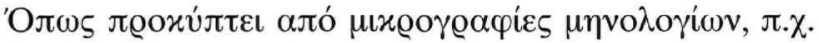

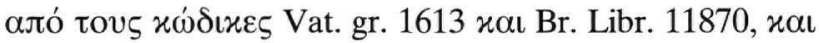

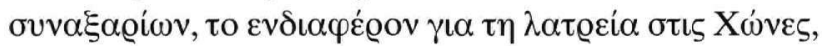

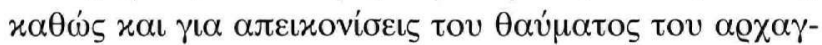

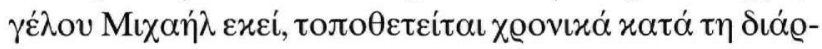

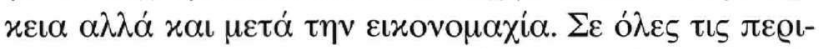

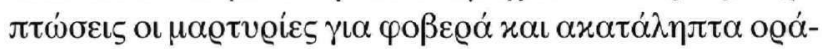

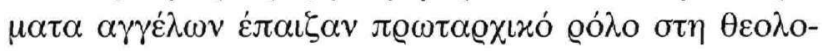

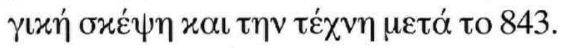

